\title{
Sports Supplement Induces Dental Structure Corrosion: An in vitro Pilot Study
}

\author{
El Suplemento Deportivo Induce Corrosión en la Estructura Dental: \\ Un Estudio Piloto in vitro
}

\author{
Lucas Thomazotti Berard'; Izabel Fernanda Machado; João Pedro dos Santos \\ Ferreira Moreira de Pinho ${ }^{3}$; Reinaldo Brito e Dias $^{1} \&$ Neide Pena Coto ${ }^{1}$
}

BERARD, L. T.; MACHADO, I. F.; PINHO, J. P. S. F. M.; DIAS, R. B. \& COTO, N. P. Sports supplement induces dental structure corrosion: An in vitro pilot study. Int. J. Odontostomat., 14(3):442-447, 2020.

\begin{abstract}
Dietary supplements are being consumed with an increasingly high frequency among sports practitioners, whether at professional and/or amateur level. The supplements contain some nutritional properties in their composition, so they can dissolute the hydroxyapatite crystals of the enamel and favor the process of dental corrosion. The objective was to measure the corrosive power of protein-based supplementation (Whey Protein), under conditions that resemble the use of the supplement by the athletes, increasing the ecological validity of the study. The teeth of the test group (TG) were placed in contact with the Whey protein solution and then exposed to artificial saliva. And the teeth of the control group (CG) were exposed only to artificial saliva. The analysis occurred in natural healthy molar teeth, so that each tooth of the TG was immersed in $50 \mathrm{~mL}$ of supplement for 1.5 minutes and then placed in contact with the artificial saliva for 30 seconds. The same procedure was performed 5 times a day for 30, 60, 90, 120, 150 and 180 days. Each group, in its time (TG0 to TG180), underwent analysis of superficial roughness with the aid of optical profilometer (Talysurf CCI ${ }^{\circledR}, 3 \mathrm{D}$ model). The control group (CG) did not change its superficial roughness. Half of the teeth of the test group (TG) suffered loss of enamel surface. The values, in micrometers, of surface loss of the TG samples were $1.21 ; 2.1 ; 2.0 ; 1.04 ; 0.97 ; 0.8 ; 0.53 ; 1.14 ; 1.9 ; 2.0 ; 1.66 ; 1.80$. The dietary supplement (Whey protein $($ ) ) may be a potential cause of the dental corrosion process, considering the demineralization of hydroxyapatite that occurs along with the surface enamel loss.
\end{abstract}

KEY WORDS: dental etching, erosive potencial, desmineralization.

\section{INTRODUCTION}

Dietary supplements have been ingested with an increasing frequency among the young and adult population, especially among sports practitioners (Bowman, 2002). This occurs due to the search for immediate results in their performance during physical activity (Middleman et al., 1998). The composition of dietary supplements impacts the athlete's health, which may compromise their oral health, because some agents, such as Citrate, Glutamate, and Aspartate present in these substances are capable of removing Calcium from the tooth enamel, in addition to removing the Calcium present in the saliva. Thus, the remineralization capacity decreases, which enhances the process of dental corrosion (Amaechi et al., 1999; Wongkhantee et al., 2006; Barbour et al., 2008).
Flavoring agents present in the formula of dietary supplements, mainly citric acid, may be responsible for dental corrosion (Cairns et al., 2002).

The term Corrosion refers to the chemical wear of the surface of the dental enamel. There are intrinsic (bulimia, gastro-oesophageal diseases) and extrinsic factors (supplement solutions, sports drinks, fruit juices, wines, soft drinks) that potentiate the corrosive process (West et al., 2003).

The process of dental corrosion presents multifactorial etiology, allowing chemical, biological and behavioral factors to influence the risk of corrosion (Nunn et al., 2003; Lussi, 2006; Lussi \&

\footnotetext{
${ }^{1}$ Department of Surgery, Prostheses and Maxillofacial Traumatology, School of Dentistry, University of São Paulo, São Paulo, Brazil

${ }^{2}$ Mechatronics and Mechanical System Engineering Departament, Polytechnic School, University of São Paulo, São Paulo, Brazil.

${ }^{3}$ Laboratory of biomechanics, School of Physical Education and Sports, , University of São Paulo, São Paulo, Brazil.
} 
Jaeggi, 2006; Kitchens \& Owens, 2007; Ehlen et al., 2008).

A recent study by Vidal et al. (2017) evaluated the corrosive potential of Maltodextrin-based dietary supplement solutions, which is a glucose polymer commonly used in sports beverages. Maltodextrin is a carbohydrate that promises to keep blood glucose levels constant during sports practice and, consequently, to increase physical performance. This substance may be a potential causative agent of the corrosion process of dental enamel, but without submitting dental elements to cycling with acidic beverages.

Thus, the objective was to measure the corrosive power of protein-based supplementation (Whey Protein), under conditions that resemble the use of the supplement by the athletes, increasing the ecological validity of the study. The hypothesis is that the absence of maltodextrin will not cause a sharp decrease in the oral $\mathrm{pH}$, not interfering in the formation of the acquired pellicle, nor causing dental corrosion.

\section{MATERIAL AND METHOD}

Experimental design. The dietary supplement Whey proteinßlsofort was used for not having maltodextrin in its formula, because according to Vidal et al., supplements containing maltodextrin decrease salivary $\mathrm{pH}$.

It is a longitudinal experiment with removal of experimental units without replacement.

pH. After dilution of the supplement studied, the solution was placed in a beaker and mixed with a magnetic stirrer (b10-b36). The $\mathrm{pH}$ of the solution was measured with a pH-meter (K39-1014B-Kasvi, São Paulo, SP, Brazil), (+ - 0.02). The value of 5.2 was obtained as a result of the $\mathrm{pH}$ measurement of the supplement studied.

Preparation of specimens. We selected 24 teeth that were exposed to the studied substance.

Test groups (TG) were formed by groups of five teeth and evaluated every 30 days for 180 days total, and, for each analysis, 4 teeth were randomly removed.

Erosive challenge. Each TG tooth was immersed for 1.5 minutes in $50 \mathrm{~mL}$ of supplement. Then it was put in contact with the artificial saliva for 30 seconds. The same procedure was performed 5 times a day, with an interval of 24 hours between each cycle, and, during this interval, all samples were kept in artificial saliva. The saliva used followed the composition reported in Table I.

Table I. Saliva composition used in the study.

\begin{tabular}{lc}
\hline Salts & Quantity $(\mathrm{g}) / \mathrm{L}$ \\
\hline Monopotassium phosphate & 3.40 \\
Sodium Phosphate Dibasic Anhydrous & 3.41 \\
Potassium Bicarbonate & 15.02 \\
Sodium Chloride & 5.84 \\
Magnesium Chloride & 0.30 \\
Calcium Chloride & 2.21 \\
Citric Acid & 4.80 \\
\hline
\end{tabular}

Optical profilometer surface analysis. Each group, in its time (TG to TG180), underwent analysis of surface roughness with the aid of optical profilometer (Talysurf $\mathrm{CCI} \otimes, 3 \mathrm{D}$ model). Data were analyzed by ProScan Software $\AA$. The differences in height between the reference and the exposed area were quantified in micrometers $(\mu \mathrm{m})$.

Each tooth had its vestibular surface measured 6 times, 3 times the region of $2 \mathrm{~mm}$ above (crown) the cervical line and 3 times the region of 1 $\mathrm{mm}$ below (root) the cervical line. Thus, the mean number of numerical findings was made to designate the values of the measured regions. The groups TG0, TG30, TG60, TG90, TG120, TG150, TG180 were formed.

Statistical procedures. A One-Sample T-test, with Bonferroni adjustment, was conducted to test the corrosion effects of the different time exposures. Therefore, the significance level was set at 0.008 $(0.05 / 6)$. We compared the difference between initial and final period of the experimental unities with zero. All statistical tests were conducted on SigmaStat 3.5 (Systat Software, Inc).

\section{RESULTS}

The main results of our study can be summarized in the following panel (Fig. 1).

The superficial analysis, with the aid of the profilometer, allowed us to record roughness values using a 3D view scale with the height of the enamel 
prisms before the immersion of the specimens in the food supplement solution (Fig. 2). The profilometer also recorded the enamel surface of the same sample after the erosive challenge of 60 days, where one can observe the decrease in the height of the enamel prisms (Fig. 3).
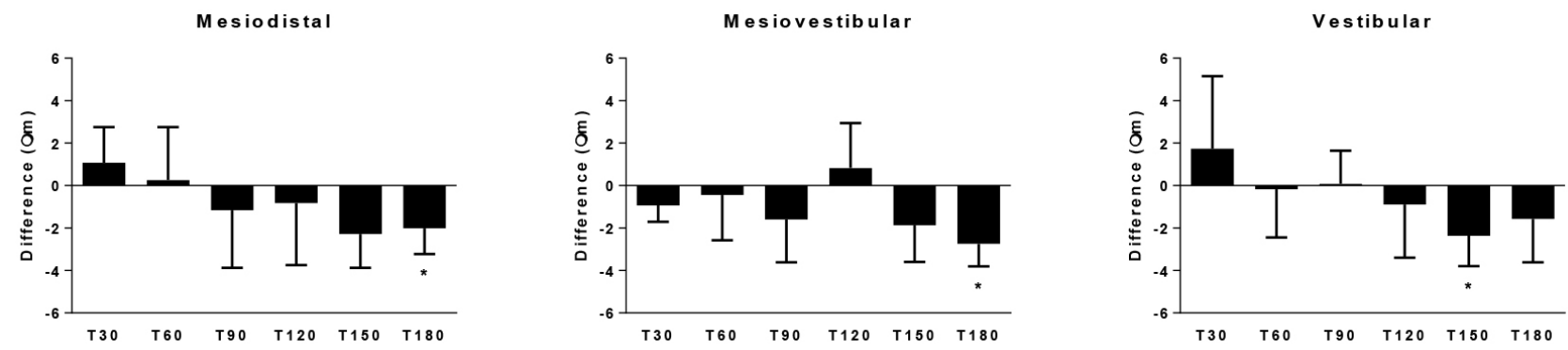

Fig. 1. Mean and standard deviation of the dental surface erosion (in $\mathrm{mm}$ ) differences between the initial period and the ith (T30 - T150) period.
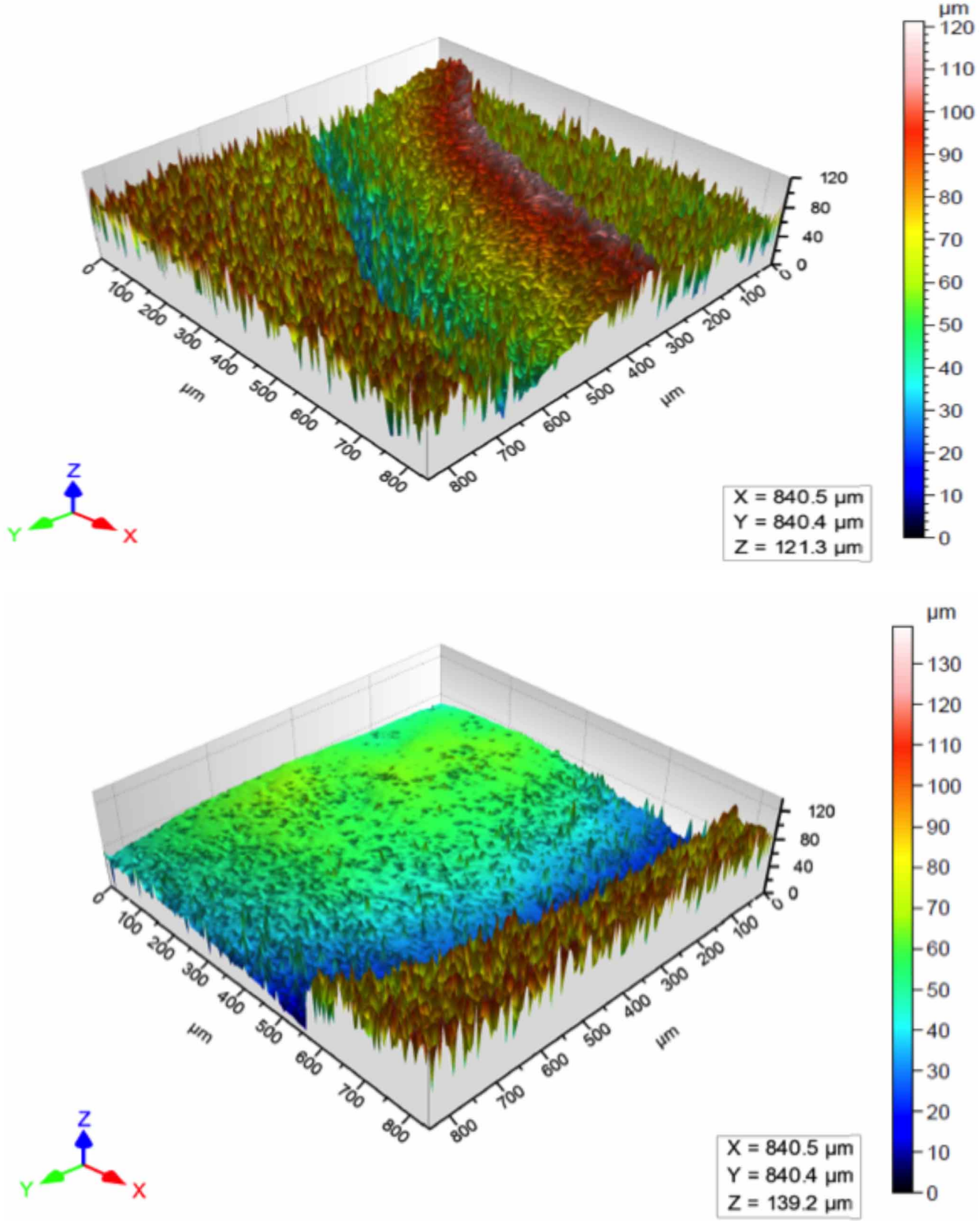

Fig. 2. Surface of dental enamel in 3D view before immersion of a sample.
Fig. 3. Surface of dental enamel in 3D view after immersion of Sample 15 (EG60). 


\section{DISCUSSION}

The objective of this research was to measure the corrosive power of dietary supplement without the presence of maltodextrin. This study presents ecological validity by submitting dental elements to erosive challenges similar to that performed by athletes during training and competitions.

In this investigation, the optical profilometer was used, which is a device that allows the topographic analysis of the surface of the most diverse materials. The superficial reading of the delineated area was performed with the laser beam emitted by the equipment, which also enables the translation into numerical data and values, in micrometers of the surface scan performed. It is an instrument of wide application, in several scales, which allowed the analysis of the degradation of the dental enamel surface and loss of the dental tissue, from the erosive challenges (Scaramucci et al., 2011), indicating thus the corrosive power of the supplement studied.

In the oral cavity, the teeth are protected by salivary film or acquired pellicle, composed of salivary glycoproteins and antibodies, through which the existence of remineralization effects is observed. The supplement, when ingested, may suffer buffering action, that is, the acidity of the beverage is minimized by the protein agents present in saliva (Amaecchi et al., 1999).

In TGs 150 and 180, a significant loss of surface roughness was observed, precisely due to the longer exposure time of the samples to the dietary supplement solution. Thus, the process of formation of the acquired pellicle was not able to curb the dental corrosion, so that the superficial loss generated in the dental enamel was more pronounced than the remineralization process. From the $\mathrm{pH}$ measurement, the value of 5.2 was verified. We also observed that the solution studied presents flavoring agents in its composition, such as Citric acid, Glutamic acid and Aspartic acid, which confer a more pleasant flavor to the supplement, but these acids contain chelating substances capable of generating the depletion of Calcium in saliva and dental enamel, contributing thus to the development of the corrosion process, as Zero in 1996 (Zero, 1996) and Cairns et al. in 2002 have shown.

Acidic beverages present different patterns of adhesion to the dental structure. We suggest that a longer time of exposure of the beverage to the tooth implies an increased risk of corrosion. This condition worsened by the fact that saliva cannot displace the film formed by the beverage on the dental surface, so that the acquired pellicle has its remineralization capacity decreased (Ireland et al., 1995; Jager et al., 2008).

The development of beverages with addition of Calcium and Phosphate ions was considered; however, we found that the addition of these ions confers a metallic flavor to the beverage (West et al., 2001). Researchers suggest that proteins adsorbed to enamel could modify the dissolution process of this substrate. Because of this property, the addition of proteins in acidic beverages could be a strategy to minimize corrosive wear (Ramalingam et al., 2005). Given this context, the incorporation of casein, protein from the group of phosphoproteins and found in milk, would imply the reduction in the dissolution rate of hydroxyapatite, regardless of the $\mathrm{pH}$ value of the acid substance (Jensdottir et al., 2005).

The injuries resulting from the ingestion of acidic beverages are more frequently found by vestibular in the cervical third of the anterior teeth, although there is the possibility of occurring in any region of the dental element. The cervical area is usually the most affected because the self-cleaning is lower than in other regions and, with this, the acid remains at this site for a longer period. Saliva does not act quickly in this location and its buffering effect takes longer to occur (Fuller \& Johnson, 1977; Levitch et al., 1994). Also, the enamel layer of the cervical region is thinner, which favors the higher prevalence of non-carious lesions in this portion of the dental element (Borcic et al., 2004). Thus, in this study, we investigated only the region that is more susceptible to loss of enamel structure, where there was no pattern of superficial enamel loss per region, since this loss could be observed in the three areas analyzed (mesiodistal, mesiovestibular, vestibular).

For an athlete, these deleterious effects are accentuated because there is a decrease in salivary flow and an increase in the concentration of total salivary protein, as a consequence of a state of dehydration during physical activity (Walsh et al., 2004). Thus, it is important that the dentist promotes the orientation of healthy practices among users of dietary supplements, whether professional athletes, amateurs or regular practitioners of physical activities, such as the decrease in the time in which they remain in contact 
with the dental elements and the reduction in the frequency of use of these beverages, especially among those individuals who have the habit of drinking other beverages considered acidic, such as soft drinks, fruit juices, energy and isotonic drinks (Ablal et al., 2009). The primary consequences of the indiscriminate use of acidic beverages such as dietary supplement are dentin hypersensitivity and non-carious cervical lesion (Wongkhantee et al.). It is also noteworthy that brushing should not be performed immediately after ingestion of carbonated beverages, because these processes associated, by mechanical action, promote the fragilization of hydroxyapatite crystals, increasing the corrosion (Devlin et al., 2006; Sundaram et al., 2007). In this sense, a previous mouthwash with an alkaline solution is recommended in an attempt to minimize the disorganization of enamel prisms (Eccles, 1979).

This pilot study sought to bring a realistic and ecological analysis of the nutritional habit of many athletes, and it should be considered for studies with greater robustness. However, it brings important clinical relevance, since it indicated a corrosive power of the supplement without maltodextrin.

The evidence from the results of this study suggests that the dietary supplement (Whey protein $®$ ) may be a potential cause of the dental corrosion process, considering the demineralization of hydroxyapatite that occurs along with the enamel surface loss.

BERARD, L. T.; MACHADO, I. F.; PINHO, J. P. S. F. M.3; DIAS, R. B. \& COTO, N. P. El suplemento deportivo induce corrosión en la estructura dental: Un estudio piloto in vitro. Int. J. Odontostomat., 14(3):442-447, 2020.

RESUMEN: Los suplementos dietéticos se consumen con una frecuencia cada vez más alta entre los practicantes de deportes, sea a nivel profesional y / o aficionado. Los suplementos contienen algunas propiedades nutricionales en su composición, por lo que pueden disolver los cristales de hidroxiapatita del esmalte y favorecer el proceso de corrosión dental. El objetivo fue medir el poder corrosivo de la suplementación a base de proteínas (proteína de suero), en condiciones que se asemejan al uso del suplemento por parte de los atletas, aumentando la validez ecológica del estudio. Los dientes del grupo de prueba (TG) se pusieron en contacto con la solución de proteína de suero y luego se expusieron a saliva artificial. Y los dientes del grupo de control (CG) estuvieron expuestos solo a saliva artificial. El análisis se realizó en dientes molares sanos naturales, cada diente del TG se sumergió en $50 \mathrm{ml}$ de suplemento durante 1,5 minutos y luego se puso en contacto con la saliva artificial durante 30 segundos. El mismo procedimiento se realizó 5 veces al día durante 30,60, 90, 120, 150 y 180 días. Cada grupo, en su momento (TG0 a TG180), se sometió a un análisis de rugosidad superficial con la ayuda de un perfilómetro óptico (Talysurf $\mathrm{CCI}$ (, modelo 3D). El grupo de control (CG) no cambió su rugosidad superficial. La mitad de los dientes del grupo de prueba (TG) sufrieron pérdida de la superficie del esmalte. Los valores, en micrómetros, de pérdida de superficie de las muestras de TG fueron $1.21 ; 2.1 ; 2,0 ; 1.04 ; 0,97 ; 0.8 ; 0,53 ; 1.14 ; 1.9 ; 2,0$; 1,$66 ; 1.80$. El suplemento dietético (Whey protein ${ }^{\circledR}$ ) puede ser una causa potencial del proceso de corrosión dental, considerando la desmineralización de la hidroxiapatita que ocurre junto con la pérdida de esmalte superficial.

PALABRAS CLAVE: grabado dental, potencial erosivo, desmineralización.

\section{REFERENCES}

Ablal, M. A.; Kaur, J. S.; Cooper, L.; Jarad, F. D.; Milosevic, A.; Higham, S. M. \& Preston, A. J. The erosive potential of some alcopops using bovine enamel: an in vitro study. J. Dent., 37(11):835-9, 2009

Amaechi, B. T.; Higham, S. M. \& Edgar, W. M. Techniques for the production of dental eroded lesions in vitro. J. Oral Rehabil., 26(2):97-102, 1999

Barbour, M. E.; Shellis, R. P.; Parker, D. M.; Allen, G. C. \& Addy, M. Inhibition of hydroxyapatite dissolution by whole casein: the effects of $\mathrm{pH}$, protein concentration, calcium, and ionic strength. Eur. J. Oral Sci., 116(5):473-8, 2008

Borcic, J.; Anic, I.; Urek, M. M. \& Ferreri, S. The prevalence of noncarious cervical lesions in permanent dentition. J. Oral Rehabil., 31(2):117-23, 2004.

Bowman, S. A. Beverage choices of young females: changes and impact on nutrient intakes. J. Am. Diet. Assoc., 102(9):1234-9, 2002.

Cairns, A. M.; Watson, M.; Creanor, S. L. \& Foye, R. H. The pH and titratable acidity of a range of diluting drinks and their potential effect on dental erosion. J. Dent., 30(7-8):313-7, 2002.

Devlin, H.; Bassiouny, M. A. \& Boston, D. Hardness of enamel exposed to Coca-Cola and artificial saliva. J. Oral Rehabil., 33(1):26-30, 2006.

Eccles, J. D. Dental erosion of nonindustrial origin. A clinical survey and classification. J. Prosthet. Dent., 42(6):649-53, 1979.

Ehlen, L. A.; Marshall, T. A.; Qian, F.; Wefel, J. S. \& Warren, J. J. Acidic beverages increase the risk of in vitro tooth erosion. Nutr. Res., 28(5):299-303, 2008

Fuller, J. L. \& Johnson, W. W. Citric acid consumption and the human dentition. J. Am. Dent. Assoc., 95(1):80-4, 1977.

Ireland, A. J.; McGuinness, N. \& Sherriff, M. An investigation into the ability of soft drinks to adhere to enamel. Caries Res., 29(6):470-6, 1995.

Jager, D. H.; Vieira, A. M.; Ruben, J. L. \& Huysmans, M. C. Influence of beverage composition on the results of erosive potential measurement by different measurement techniques. Caries Res., 42(2):98-104, 2008.

Jensdottir, T.; Bardow, A. \& Holbrook, P. Properties and modification of soft drinks in relation to their erosive potential in vitro. J. Dent., 33(7):569-75, 2005. 
Kitchens, M. \& Owens, B. M. Effect of carbonated beverages, coffee, sports and high energy drinks, and bottled water on the in vitro erosion characteristics of dental enamel. J. Clin. Pediatr. Dent., 31(3):153-9, 2007.

Levitch, L. C.; Bader, J. D.; Shugars, D. A. \& Heymann, H. O. Noncarious cervical lesions. J. Dent., 22(4):195-207, 1994.

Lussi, A. \& Jaeggi, T. Chemical factors. Monogr. Oral Sci., 20:77-87, 2006.

Lussi, A. Erosive tooth wear - a multifactorial condition of growing concern and increasing knowledge. Monogr. Oral Sci., 20:1-8, 2006.

Middleman, A. B.; Vazquez, I. \& Durant, R. H. Eating patterns, physical activity, and attempts to change weight among adolescents. J. Adolesc. Health, 22(1):37-42, 1998.

Nunn, J. H.; Gordon, P. H.; Morris, A. J.; Pine, C. M. \& Walker, A. Dental erosion -- changing prevalence? A review of British National childrens' surveys. Int. J. Paediatr. Dent., 13(2):98-105, 2003.

Ramalingam, L.; Messer, L. B. \& Reynolds, E. C. Adding casein phosphopeptide-amorphous calcium phosphate to sports drinks to eliminate in vitro erosion. Pediatr. Dent., 27(1):61-7, 2005.

Scaramucci, T.; Hara, A. T.; Zero, D. T.; Ferreira, S. S.; Aoki, I. V. \& Sobral, M. A. P. Development of an orange juice surrogate for the study of dental erosion. Braz. Dent. J., 22(6):473-8, 2011.

Sundaram, G.; Wilson, R.; Watson, T. F. \& Bartlett, D. W. Effect of resin coating on dentine compared to repeated topical applications of fluoride mouthwash after an abrasion and erosion wear regime. J. Dent., 35(10):814-8, 2007.

Vidal, M. G.; de Oliveira, P. H. C.; Lima-Arsati, Y. B. O. \& Rodrigues, J. A. The effect of dilution on the erosive potential of maltodextrincontaining sports drinks. Rev. Odontol. UNESP, 46(1):28-32, 2017.

Walsh, N. P.; Montague, J. C.; Callow, N. \& Rowlands, A. V. Saliva flow rate, total protein concentration and osmolality as potential markers of whole body hydration status during progressive acute dehydration in humans. Arch. Oral Biol., 49(2):149-54, 2004.

West, N. X.; Hughes, J. A. \& Addy, M. The effect of pH on the erosion of dentine and enamel by dietary acids in vitro. J. Oral Rehabil., 28(9):860-4, 2001.

West, N. X.; Hughes, J. A.; Parker, D. M.; Moohan, M. \& Addy, M. Development of low erosive carbonated fruit drinks 2. Evaluation of an experimental carbonated blackcurrant drink compared to a conventional carbonated drink. J. Dent., 31(5):361-5, 2003.

Wongkhantee, S.; Patanapiradej, V.; Maneenut, C. \& Tantbirojn, D. Effect of acidic food and drinks on surface hardness of enamel, dentine, and tooth-coloured filling materials. J. Dent., 34(3):21420, 2006.

Zero, D. T. Etiology of dental erosion--extrinsic factors. Eur. J. Oral Sci., 104(2 Pt. 2):162-77, 1996.
Corresponding author:

Lucas Thomazotti Berard

Department of Maxillofacial Surgery

Prosthetics and Traumatology

School of Dentistry

University of São Paulo

Av. Prof. Lineu Prestes, 2227

Cidade Universitária, 05508-900

São Paulo - SP

BRAZIL

E-mail: lucas.berard@usp.br

\author{
Corresponding author: \\ Dr. Neide Pena Coto \\ Department of Surgery \\ Prostheses and Maxillofacial Traumatology \\ School of Dentistry \\ University of São Paul \\ Avenida Lineu Prestes \\ 2227 Cidade Universitária \\ São Paulo/SP \\ BRAZIL
}

Email: npcoto@usp.br

Received: 13-02-2020

Accepted: 20-04-2020 